\title{
側面励起型高出力Yb:YAGコンポジットディスクレーザー
}

\author{
山本 修平, 柳澤 隆行, 平野 嘉仁 \\ 三菱電機(株)情報技術総合研究所 ( ₹247-8501 神奈川県鎌倉市大船5-1-1)
}

High Power Side-Pumped Yb:YAG Composite Disk Laser

Syuhei YAMAMOTO, Takayuki YANAGISAWA, and Yoshihito HIRANO

Information Technology R\&D Center, Mitsubishi Electric Corporation, 5-1-1, Ofuna Kamakura, Kanagawa 247-8501

(Received November, 12)

\begin{abstract}
Thin disk geometry for laser active medium has advantages for high-average-power operation with good beam quality. However it is difficult to obtain high pumping efficiency due to the small thickness of the crystal. To improve the pumping efficiency, we have developed a side-pumped Yb:YAG/YAG composite disk laser with a stacked-LD tight-focusing technique. The maximum output power was $235-\mathrm{W}$ from one disk with the optical efficiency of 0.38 .
\end{abstract}

Key Words: Lasers, Solid-state, Diode-pumped, Disk laser, Yb:YAG

1.はじめに

高出力の固体レーザーでは, レーザー媒質の発生熱に よる熱レンズ，熱複屈折，熱歪みが発生し，効率やビー ム品質を劣化させるという問題がある。このため, 様々 な固体レーザー媒質の形状，および，励起方式が提案さ れ, 高出力化, 高輝度化の研究が行われてきた。今回, 我々はコンポジット構造をもつ薄ディスク型Yb:YAGを用 いた，高出力レーザー装置の開発を行った。ディスク型 固体レーザーは，発生熱をレーザー光軸方向に排熱する 構成により，温度勾配がレーザー光軸方向に発生するた め, 理想的にはレーザー光断面方向に屈折率分布が発生 しない.このため, 励起パワーの変化によるビームモー ドの変化やビーム品質の劣化が少なく, 出力の拡張性 や, 高出力, 高ビーム品質レーザー光の発生に適した方 式として期待されている.

本稿では，高出力レーザーとしての固体レーザー媒質 の形状ごとの特徵，および, Yb:YAG薄ディスクレーザー の現状について示した後, 側面励起型Yb:YAGコンポジッ トディスクレーザーの開発結果について紹介する。

\section{2. 各種固体レーザー媒質の形状と特徵}

固体レーザー媒質の形状は，主に，(1)ロッド型，(2)ス ラブ型，（3）ファイバー型，(4)ディスク型に大別できる. それぞれの形状ごとの主な特徴と近年の進展は以下の通 りである。

\section{1 ロッド型}

ロッド型は，製作，保持などが簡便なことから，固体 レーザーとしては, 現在, 最も一般的な構成である. レーザー光は円形ロッドの中心を伝搬し, 排熱はロッド の側面から行われる。側面全体から排熱を行うことが可 能なため, 冷却が容易であるが，ロッドの中心から側面 に向けての温度勾配が発生し，ロッド断面内で温度や光 弾性効果に基づく屈折率分布が生じる。これがロッド内 を通過するレーザー光にレンズ効果や複屈折効果といっ た光学的な歪みを与え, 高出力動作時のビーム品質や出 力効率を劣化させるという問題がある。ロッド型固体 レーザーの高出力動作では, Nd:YAGロッドを6本直列に 配置することにより, 出力 $12 \mathrm{~kW}$ が電気効率 $23 \%$ で得られ ている1．また，熱レンズ，および，熱複屈折を2本の ロッドと90度ローテータで補償することにより2)， $\mathrm{M}^{2}=$ 2.2 で532WのQスイッチ出力3)や， $\mathrm{M}^{2}=1.1$ で出力 $200 \mathrm{~W}$ 超高輝度動作 ${ }^{4)}$ が報告されている.

\section{2 スラブ型}

スラブ型では，対向した二つの側面から励起光を入射 し，それに垂直な二つの側面から排熱を行う構成が一般 的である。この構成の特徵は, 温度勾配がスラブの排熱 方向にのみに生じることである。これにより，光学的歪 みの異方性がスラブの排熱方向, および，排熱方向に直 交した方向にのみ発生するため, 直線偏光のレーザー発 振が容易に得られる。また, 側面が平面のため, 結晶の 保持，および，冷却が容易である。ささらに，GE社のMartin等により考案されたジグザグスラブ方式5)では，冷却面 
間を 1 往復したときの位相変化が，レーザービーム内の全 ての点において平均化され, 理想的には熱レンズ効果が 発生しない. 従って, レーザー媒質内での熱的に発生す る光学歪みの補償という点で, 本発明は理想的には非常 に優れている。しかし，多数回のジグザグ反射を用いる ため, 反射面の平行度, 面精度への要求が厳しく, 製作 性が悪くなるとともに, 発生熱による反射面の変形が レーザービームに波面収差を与える問題もある。また， 平面で囲まれているため, 高出力励起時には寄生発振の 抑制が課題となる。高出力動作では, Nd:YAGスラブで単 機出力 $6.1 \mathrm{~kW} ， 2$ 機合成出力 $10.2 \mathrm{~kW}$, 電気効率 $20.1 \%$ \%報 告されている6). また, 高輝度動作ではNd:YAGで連続出 力 $380 \mathrm{~W}$, 光-光変換効率 $34 \%, \mathrm{M}^{2}=1.8$ が, $\mathrm{Yb}: \mathrm{YAG}$ で連 続出力 $228 \mathrm{~W}$, 光-光変換効率 $18 \%, \mathrm{M}^{2}=1.27 \times 1.44^{7)}$ が報 告されている.

\section{3 ファイバー型}

ファイバー型は，ロッドに比ベてアスペクト比が非常 に大きいため, 単位長さあたりの熱負荷が小さく, 大き な利得が得られる。このため, 熱的な出力制限が緩く, 高出力化が容易である。 また, 誘導放出断面積の小さな 活性イオンを用いた場合でも，高効率なレーザー発振が 可能である.さらに，モードが導波路により形成される ため, 熱によるビーム品質の劣化がほとんど無く, 高輝 度・高効率動作が可能である。一方，コア径が小さいた め, コア内のパワー密度が大きくなり, 特に高ピークの パルス動作では, 端面破壊や非線形効果により出力が制 限される。このため, 高出力化は主に連続 $(\mathrm{CW})$ 動作で行 われており，コア径の大きなファイバーを用いてパワー 密度を低減したり ${ }^{8)}$, エンドキャップ構造を施したりする ことによりダメージを克服している，また，高い利得の ため戻り光などの影響を受けやすいなどの課題もある. 近年の報告としては，マルチモード動作で出力 $10 \mathrm{~kW}$ 級 レーザー装置が市販されており1), 高輝度動作では出力 $1.3 \mathrm{~kW} ， \mathrm{M}^{2}<3^{8)}$ が報告されている.ファイバーレーザー は, CW動作においては最も輝度の高いレーザーに発展し ている.

\section{4 ディスク型}

ディスク型は，ジグザグスラブと同時期に，同じGE社 のAlmasi等により考案された . 励起構成やディスク形状 等の違いにより, アクティブミラー, シン(薄)ディス ク10), マイクロチップ11,12) と呼ばれることもある. 本方 式の特徵は, レーザー光軸と排熱方向が同方向で, 温度 勾配がレーザー光軸方向に発生するため, レーザー光の 断面内に屈折率分布が生じないことである。従って共振 器の設計で励起パワーによる熱レンズの变化を考える必 要がなく, 利得を持った反射ミラーとしてディスク枚数 を増やすことができるので，パワースケーリングが容易 である。一方で, ディスク内の発熱分布がそのまま温度 分布となるため, 励起分布が均一でない場合には, 温度 差に起因する屈折率分布による収差が発生する。また, 厚さが薄いため, 応力による光学的な歪みが発生しゃす
い.さらに, 薄いレーザー媒質に高効率に励起光を吸収 させることが課題となっている．近年の報告としては, Giesen等により, 端面励起方式で出力 $1 \mathrm{~kW}$ が報告されてお り10), 同方式で4 kW級レーザー装置が市販されている.

\section{Yb:YAG薄ディスクレーザーの現状}

$\mathrm{Yb}$ 系固体レーザー媒質は, 励起波長とレーザー発振波 長が近く，ストークスシフトに起因する原子量子効率が 高い。また，レーザー上位準位より上の準位を持たない ため,アップコンバージョンがほとんど存在せず，量子 効率が高い. 従って, 励起による発熱が小さく, 高出 力・高効率動作に適している．特に, Yb:YAGは熱伝導率 が高く温度上昇を最小限に抑えることができるので，次 世代の高出力 · 高効率レーザーとして期待されている.

また，Yb:YAGは，利得幅が広いことから超短パルスの 発生が可能であり, ホストによる違いでさらに広い利得 帯域が得られる。また, 薄ディスク形状では, レーザー 光軸方向の伝搬長が小さいことからレーザー媒質上での 波長分散が小さく抑えられ，超短パルス発生に適してい

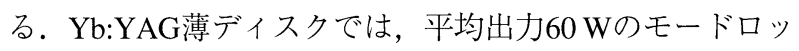
ク出力が $810 \mathrm{fs}$ で得られ ${ }^{13)}$, Yb:KYWでは, $71 \mathrm{fs}$ 超短パ ルス光の発生が報告されている14)，LDにより直接励起が できないTi:Sapphireに比べて, 小型, 高効率な超短パルス レーザーを製作することが可能である.

一方, $\mathrm{Yb}$ 系固体レーザー媒質は, 準3準位系のエネル ギー準位を有するため, 利得を生じさせるためには下準 位吸収を飽和させる必要がある。従って, 常温動作では 高密度励起が必要であり, 発熱密度が高くなることから レーザー媒質の温度が上昇しやすい. さらに, レーザー 媒質の温度上昇に伴い利得が低下するため, 高効率動作 のためには効率的な排熱が課題となる．薄ディスク型 レーザー媒質では, 薄ディスクの広い排熱面から厚さ方 向に冷却を行うため, レーザー媒質の温度上昇は最小限 に抑えられる。このため, 準3準位系レーザー媒質である Yb:YAGに適した構成である.

レーザー媒質の温度上昇を考えた場合，厚さはできる だけ薄いことが望ましい.しかし, 薄い結晶に高出力の 励起光を吸収させることが課題となる. $\mathrm{Yb}: \mathrm{YAGでは \textrm {Yb } ^ { 3 + }}$ のイオン半径が $\mathrm{Y}^{3+}$ のイオン半径に近いため, $\mathrm{Yb}^{3+}$ 高濃 度添加が可能であり，濃度消光が起きにくい．高濃度添

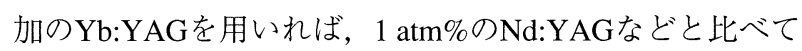
も数倍高い吸収係数を持つことが可能であるが, 媒質厚 さが100 400 $\mu \mathrm{m}$ 程度の薄ディスクにおいては, 端面から のダブルパルス励起では，十分な吸収長が得られず，ま た，側面励起では，薄いディスクの側面に輝度の低い高 出力LD光の出力を集光する必要があり, 高効率に励起光 を吸収させることが困難である。このため, 励起構成に ついて様々な方式が提案されている.

端面励起方式では, Fig. 1のマルチパス端面励起方式10) のように，ファイバーから出射した励起光をパラボラミ ラーで薄ディスク端面に複数回集光することにより, 吸 収長を増加させ, 高効率吸収を実現している. 側面励起 


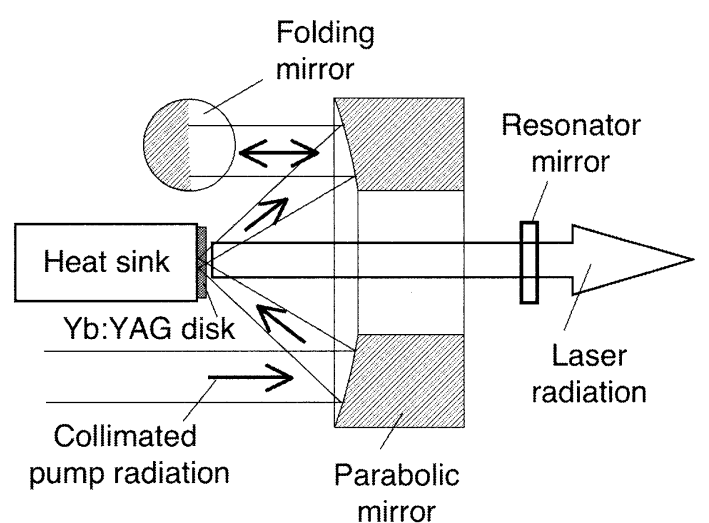

Fig. 1 Principal setup of the quasi-end pumped geometry. ${ }^{10)}$

方式では, Fig. 2に示すように，比較的輝度の高いファイ バー結合型LDの出力をレンズで集光し，ディスクのエッ ジから励起を行う方式15,16)や，レンズダクトを用いてディ スクの側面から励起を行う方式 ${ }^{17)}$ が提案されている。側 面からの励起では，ディスク厚さによらず長い吸収長が 得られるため, 高い吸収率が容易に得られる。しかし， 励起光を導入する側面の面積が小さいため, 例えば，励 起源として発光面積の大きいスタックLDを用いて高出力 化をはかることが難しい. ディスクの厚さを厚くすれば 入射効率を上げることが可能であるが，薄ディスクレー ザー媒質の表面温度は厚さに比例して増加するため，利 得を低下させ，効率を低下させてしまう。このためレー ザー媒質の厚さを厚くすることなく高効率に励起光を入 射する励起方式の開発が課題であった。

\section{4. 側面励起型高出力Yb:YAGコンポジット ディスクレーザーの開発}

\section{1 励起構成}

Fig. 3に, 今回開発したYb:YAG ディスクレーザーの励 起構成を示す. Yb:YAGディスク表面にUndoped YAGディ スクを接合したコンポジットディスク構成とすること で，Yb:YAGの厚み増加にともなう温度上昇を抑えると同

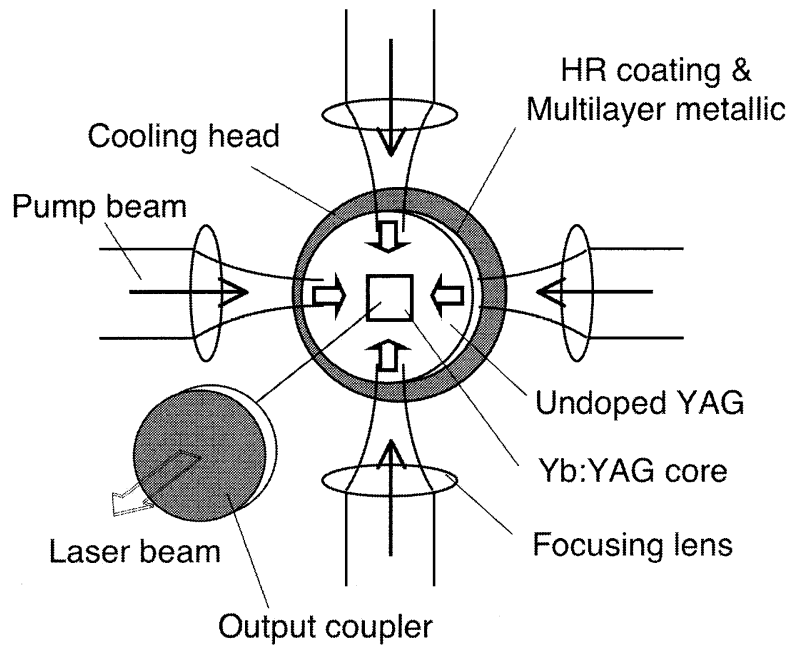

Fig. 2 The microchip composite Yb:YAG laser. ${ }^{16)}$
Top view

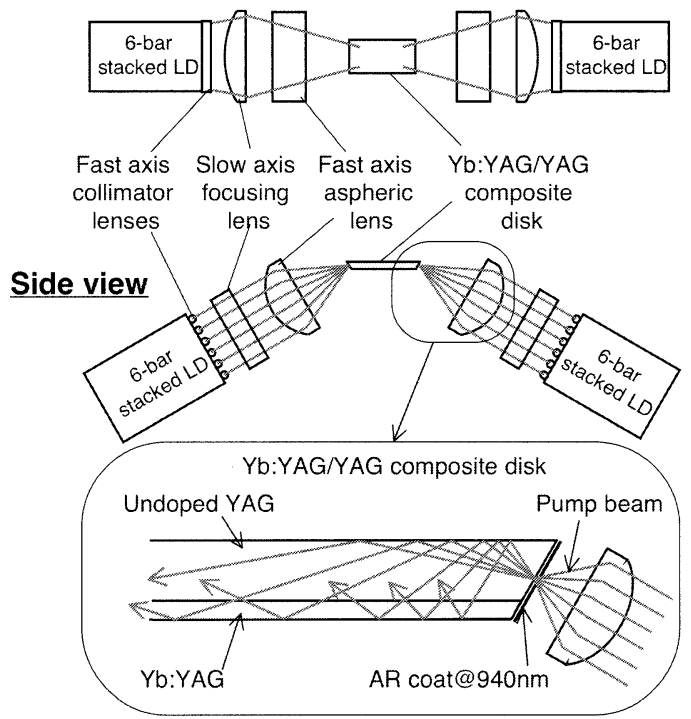

Fig. 3 Configuration of side-pumped Yb:YAG disk module.

時に, 励起光を導入する側面の面積を拡大して, 励起光 の入射効率の向上をはかった。コンポジットディスク は，サイズが $8 \times 4 \times 0.4 \mathrm{~mm}$ であり，0.1 mm厚，濃度10 atm\% のYb:YAGに, $0.3 \mathrm{~mm}$ 厚のUndoped YAGを光学的に接合し て製作した。コンポジットディスクの上下面には，入射 角度 $60^{\circ}$ でのレーザー光 $(1030 \mathrm{~nm})$ に対するARコート，HR コートをそれぞれ施し，アクティブミラーとして動作さ せる．励起光源には，スタックLDの高集光技術4を適用 した。波長 $940 \mathrm{~nm}$ の速軸コリメー夕付きの6バースタック LDを2個対向させ, 速軸・遅軸2枚のシリンドリカルレン ズにより $9.5 \mathrm{~mm}$ (速軸方向) $\times 10 \mathrm{~mm}$ (遅軸方向)の発光面 積を，コンポジットディスク側面上で $0.4 \mathrm{~mm} \times 4 \mathrm{~mm}$ に縮 小することで，微小側面からの励起を可能とした。励起 光の速軸方向は, $\mathrm{LD}$ バーごとに速軸コリメータレンズで 平行化した後に，速軸集光レンズで一括集光し，波長940 $\mathrm{nm}$ のARコートが施されたコンポジットデイスクの励起光 入射側面からコンポジットディスク内に入射する。速軸 コリメータレンズ後の励起LD出力からコンポジットディ スク内への輸送効率は93\%である。コンポジットディス ク内に入射した励起光は，それぞれのLDバーごとに異な る角度でコンポジットディスク内の上下面間で反射しな がら伝搬し，Yb:YAG部を通過する際に吸収される。従っ て，Yb:YAG部とUndoped $\mathrm{YAG}$ 部の厚さの比を変えること により，実効的な吸収係数を調整することが可能であ る。製作したコンポジットディスクはYb:YAGとUndoped YAGの厚さの比が1：3であるため，実効的な吸収係数は 濃度10 atm\%のYb:YAGの1/4となる。このときの吸収飽和 を含まない小信号吸収効率は，測定では87\%であった。

\section{2 冷却構成}

Fig. 4にYb:YAGディスクレーザーの冷却構成を示す. $0.1 \mathrm{~mm}$ 厚のYb:YAGディスクを用いた $0.4 \mathrm{~mm}$ 厚のコンポ ジットディスクとしているため, $0.4 \mathrm{~mm}$ 厚のYb:YAGディ 


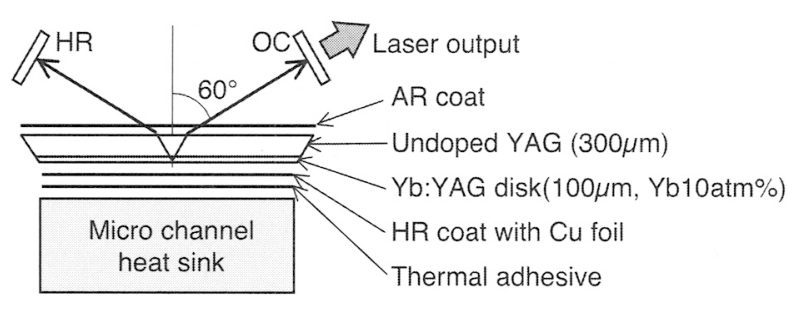

Fig. 4 Configuration of cooling system.

スクである場合に比べ，Yb:YAG部での温度上昇を $1 / 4 に$ 低減している，HRコートは，誘電体多層膜に銅薄膜を施 すことで，高反射率を維持したまま，熱伝導率の低い誘 電体多層膜の厚さを低減している。コンポジットディ久 クは, マイクロチャネルで水冷却した銅のヒートシンク に導電性接着剤を用いて固定し，高い熱伝導度を実現す るとともに，゙ィスクにかかる応力を接着剤の弾力性に より低減している。レーザー発振光は入射角度 60 ○゙゙ディ スクに入射し，発振光に対する見かけのビーム径を保っ たまま，ディスクの大きさを2倍に搪大している。これに より, 発熱密度を $1 / 2$ とし, Yb:YAGの温度上昇を低減し た。

Fig. 5にディスク中心付近での厚み方向の温度分布の測 定結果を示す。測定では非接触の温度センサを用いた。 最大励起LD出力 $626 \mathrm{~W}$ (速軸コリメータレンズ後) 時, 冷却 水から Yb:YAGディスク上面までの全温度上昇は $94{ }^{\circ} \mathrm{C}$,

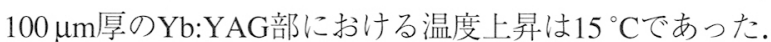
同じ励起密度の $400 \mu \mathrm{m}$ 厚のYb:YAGを用いた場合, Yb: $\mathrm{YAG}$ 部に扮ける温度上昇は $60{ }^{\circ} \mathrm{C}$ なるため, コンポジッ トディスク構造とすることにより $45{ }^{\circ} \mathrm{C} の$ 温度低減をは かった。

\section{3 開発結果}

Fig. 6に励起分布の測定結果を示す. 励起光伝搬方向の 励起分布は，入射角度の異なる各励起光の合成の分布之 なるため，全体としてはほぼフラットであるものの，小 さいピッチで強弱のある分布であることが確認された。 また, 励起光の遅軸方向の励起分布は, 遅軸方向の集光 点における強度分布を反映し, 中心が強い山型の分布に なることが確認された。

Fig. 7にマルチモード動作におけるレーザー入出力特性

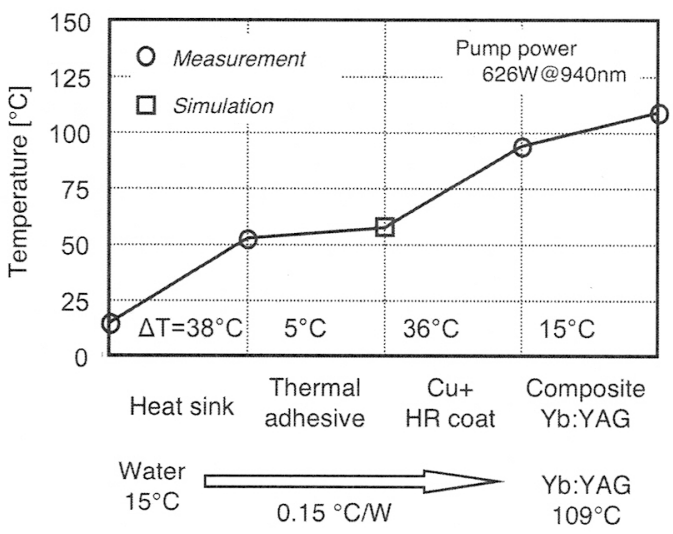

Fig. 5 Temperature rise without oscillation.

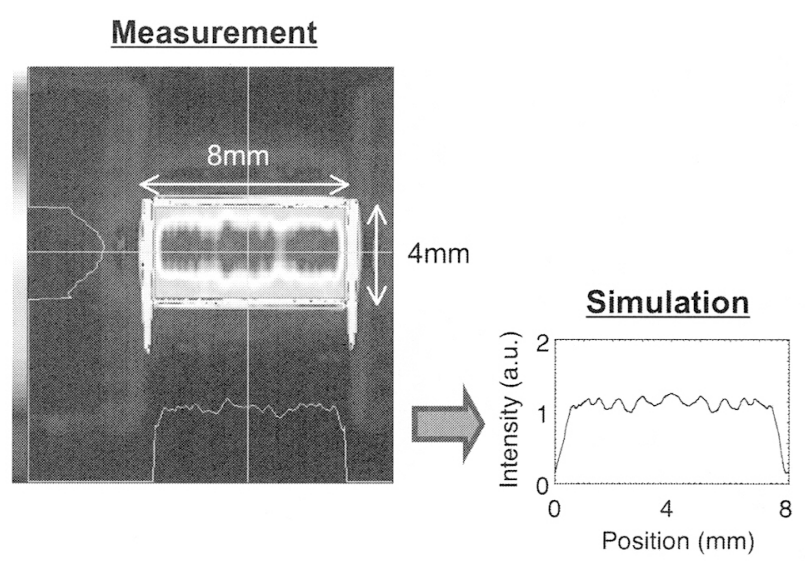

Fig. 6 Pumping distribution.

を示吉。出力鏡反射率 $96.5 \%$, 凹面の全反射鏡曲率 $0.3 \mathrm{~m}$, 共振器長 $73 \mathrm{~mm}$ とした. 励起LD出力 $626 \mathrm{~W}$ 時にレーザー出 力 $235 \mathrm{~W}$ がスロープ効率 $42 \%$, 光一光変換効率 $37.5 \%$ で得 られた。励起光の吸収飽和と Yb:YAGの温度变化による利 得の変化を考慮したレート方程式による計算結果と良い 一致を示した。このときのビーム伝搬因子 $\mathrm{M}^{2}$ は，152(長 軸方向 $) \times 65$ (短軸方向)であった。

さらに，共振器長，および，全反射鏡曲率の条件を変 えることで，モード選択開口として用いているYb:YAG ディスク上のビームモードサイズを変更し，異なるビー ムモードでの動作を行った. Table 1に最大励起LD出力626 $\mathrm{W}$ 時の，各ビームモードに拈けるビーム伝搬因子 $\mathrm{M}^{2}$ と レーザー出力の測定結果を示す。発振光が低次モードに なるに従いレーザー出力が低下し， $\mathrm{M}^{2}=11 \times 10$ でレーザー 出力は $110 \mathrm{~W}, \mathrm{M}^{2}=3.8 \times 6.2$ で出力 $49 \mathrm{~W}$ であった。低次 モード動作時にレーザー出力が低下する要因として，励 起時のディスク面内の波面収差の増加が上げられる. Zygo干渉計で測定した反射往復時の波面収差は，未励起 時には0.1 $\lambda(\mathrm{rms})(\lambda=1030 \mathrm{~nm})$ 以下と小さいものの, 励起 時には温度差によりディスク面全体で $0.4 \lambda(\mathrm{rms})$ にまで増 加する。 これに加え，Fig. 6に見られる励起光伝搬方向の 不均一な励起分布が温度分布を作り，ディスク面内に高 次の波面収差を発生させている。このために，低次モー ドでは損失が増加し, 出力の低下を招いていると考えら れる。ロッド型やスラブ型では, 排熱方向が光軸と直交 して扔り，励起分布の高次の不均一さが，波面収差とし て発振光に与える影響は小さい。一方, 薄ディスク型で は，温度分布を形成し波面収差を与えるため，高次の不

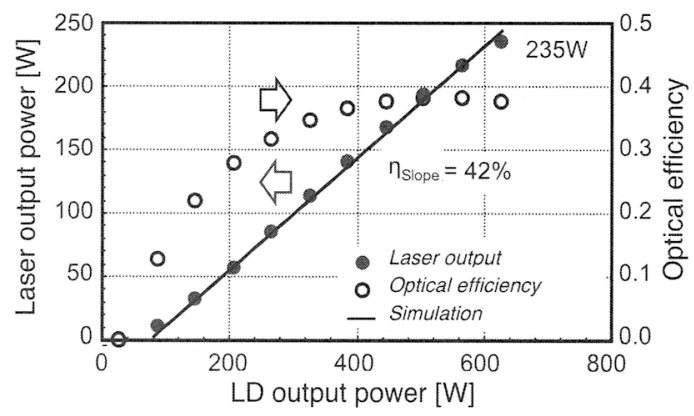

Fig. 7 Laser output results: Multimode operation. 
Table 1 Beam propagation factor dependence of laser output power.

\begin{tabular}{ccc}
\hline \hline LD output power (W) & Beam propagation factor $: \mathrm{M}^{2}$ & Laser power $(\mathrm{W})$ \\
\hline & $152 \times 65$ & 235 \\
$87 \times 41$ & 208 \\
& $50 \times 28$ & 189 \\
626 & $19 \times 18$ & 127 \\
& $11 \times 10$ & 110 \\
& $5.1 \times 8.4$ & 60 \\
& $3.8 \times 6.2$ & 49 \\
\hline \hline
\end{tabular}

均一成分が熱伝導を通じて媒質内に波面収差を形成する ことが問題となる。このため, 他の媒質形状と同様に, 均一な励起分布を実現することが課題である。

\section{5. まとめ}

固体レーザー媒質の形状と励起方式のこれまでの進展 について説明し，薄ディスクレーザー媒質の特徵と課題 について示した。 また，高出力スタックLDによる高効率 励起が可能なYb:YAGコンポジットディスクを用いた，側 面励起型高出力Yb:YAGディスクレーザーの開発を行い, $\mathrm{CW}$ 出力 $235 \mathrm{~W}$, 光一光変換効率 $37.5 \%$ の高出力動作結果 について述べた，開発に扔いて，励起分布に依存して発 生するディスク面内の温度分布による高次の波面収差 が，低次モード動作の出力低下を発生させ，他の励起方 式と同様に，均一な励起分布を実現することが，ディス クレーザー開発の大きな課題であることが分かった。

\section{参考文献}

1）湯浅広士，秋山靖裕，高田弘之，西田 直人：レーザー 研究 31 (2003) 508.

2) W. C. Scott and M. Dewitt: Appl. Phys. Lett. 18 (1971) 3.

3) E. C. Honea, R. J. Beach, S. C. Mitchell, J. A. Skidmore, M. A. Emanuel, S. B. Sutton, S. A. Payne, P. V. Avizonis, R. S. Monroe, and D. G. Harris: Opt. Lett. 25 (2000) 805.

4) Y. Hirano, Y. Koyata, S. Yamamoto, K. Kasahara, and T. Tajime: Opt. Lett. 24 (1999) 679.

5) W. S. Martin and J. P. Chernoch: US Patent no. 3,633,126 (1972).

6）西川祐司：レーザー研究 31 (2003) 513.

7) G. D. Goodno, S. Palese, J. Harkenrider, and H. Injeyan: OSA TOPS 50 (2001) 2.

8) A. Liem, J. Limpert, H. Zellmer, A. Tunnermann, V. Reichel, K. Morl, S. Jetschke, S. Unger, H.-R. Muller, J. Kirchhof, T. Sandrock, and A. Harschak: Postdeadline paper CLEO (OSA, 2004) CPDD2.

9) J. C. Almasi and W. S. Martin: US Patent no. 3,631,362 (1971).

10) C. Stewen, K. Contag, M. Larionov, A. Giesen, and M. Hugel: IEEE J. Sel. Top. Quantum Electron. 6 (2000) 650.

11) J. J. Zayhowski and P. L. Kelley: IEEE J. Quantum Electron. 27 (1991) 2220.

12) T. Taira, A. Mukai, Y. Nozawa, and T. Kobayashi: Opt. Lett. 16 (1991) 1955.

13) E. Innerhofer, T. Sudmeyer, F. Brunner, R. Haring, A. Aschwanden, R. Paschotta, C. Honninger, M. Kumkar, and U. Keller: Opt. Lett. 28 (2003) 367.

14) H. Liu, J. Nees, and G. Mourou: Opt. Lett. 26 (2001) 1723.

15) T. Dascalu, T. Taira, and N. Pavel: Opt. Lett. 27 (2002) 1791.

16) T. Dascalu, N. Pavel, and T. Taira: Appl. Phys. Lett. 83 (2003) 4086.

17) L. E. Zapata, R. J. Beach, and S. A. Payne: Tech. Dig. CLEO (OSA, 2001)p. 334 paper CWF3. 